\title{
Analysis on Visual Guiding Function of Graphic Elements of Tourism Posters
}

\author{
Mengmeng Zhou \\ Yantai Nanshan University \\ Yantai, China 265713
}

\begin{abstract}
The tourism poster graphics conveyed in visual information refers to the component elements excluding text in the poster. Graphics is an integral part of tourism poster. Graphics plays an important role in visual communication design. Without ideal graphics, visual communication design will become feeble. It can show the free space consciousness and freely constitute main part to use picture space as "field" to capture graphics. It is a way for artists to show their talents. It can play the potentials of designers furthest and reflect artists' personality and creative consciousness. Graphic language has an irreplaceable advantage in this regard. That is why graphic language is widely used in design of advertising poster. Both specific graphics and abstract graphics are the main communication elements in design of advertising poster which can effectively make designers' expression content visualized and pictorialized.
\end{abstract}

Keywords—tourism poster; graphic elements; visual guiding function

\section{THE CHARACTERISTICS OF TOURISM POSTER GRAPHICS}

Graphics function is mainly to convey information. Human beings have known how to use graphical symbols for information exchange very early. The prototype of the graphics can be traced back to the ancient times. The simplest graphical language can be the earliest rope knots, tree carving, rockfill and hieroglyphs. With the complexity of human thoughts and social activities, the graphics becomes more complicated.

\section{A. Specific and Visualized}

The graphics in tourism poster has the specific and visualized characteristic, so that people can directly perceive the information of the tourism poster. Designers can depict, shape and show carefully based on this characteristic, and convey information to consumers as far as possible. The specific and visualized image appeal can attract, move and guide consumers.

Graphical symbols are visual, vivid and concise, which is incomparable by text. Any art has its own unique way of expression. Graphics has a source of cultural awareness and symbolic significance. Just like grammar, graphic art is also formed by subject (object), conjunction (relationship) and predicative (characteristics). Therefore, the study of the combination of the three relationships is the focus of graphic art design in learning. Design is a branch of art. What we use is the symbolic function of graphics that is words to presentation. Its communication way has internality. That is to say, it conveys information through metaphor or symbolism, rather than through diagram or additional information. Even if there is text, its function is only auxiliary.

The word language is abstract, so people receive information coordinated with imagination. The graphics is clear and specific. People can view all information in a glance. The word language is relatively rational, while the graphic language is much visualized and perceptual. People see graphics through eyes and judge through brain with no transformational analysis. The feel process when we "read" a text is significantly different from that when we "see" a picture. It can be seen that graphics has a direct and strong advantage in information communication. If we see a picture of peace dove, we will immediately think of the theme of war and peace without much explanation. This is the charm of the graphics.

\section{B. True}

In addition to the specific and visualized characteristic of the tourism poster graphics, it is also true. At this point, it is different from the performance of pure art. Tourism poster graphics is designed by poster designers, and it belongs to the category of visual arts, but tourism poster was not a product of pure spirit. It is a perfect combination of practicability and aestheticism, and has information value, ornamental value and aesthetic value.

The word language has a national and regional character. Almost all ethnic groups have their unique language. It brings obstacles to the exchanges of different countries and ethnic groups. Graphics has broken this limitation. It surpasses the language barriers among countries and ethnic groups. The graphics is used to express and communicate intentions. Of course, graphics also has certain nationality. For example, peach in China is a symbol of longevity; peonies symbolize wealth and rank; the cross in the Western symbolizes salvation; the cannonball symbolizes war and death. The graphics is given with profound thoughts and rich connotations. The visual elements of graphics are sourced from human life and living environment, so most of them are same or similar. The ethnic and geographical differences have universality, so people are able to communicate and understand each other through graphics.

Symbolism of graphics is diversified. That is what designers diligently strive after in the creation of graphics. 
This expression effect not only depends on designers' technical means and aesthetic taste, but also depends on their growth environment, and the breadth and depth of knowledge. It sends out a gleam of thoughts and wisdom.

\section{Appeal}

Tourism poster graphics is a specific visual language. It has a strong appeal. Designers can refine text through the strong appeal of graphics in poster. The poster well takes advantage of this visual art to shape image of enterprise and commodities or convey business information.

The recognition function is the basic function of the graphic marks. As a special symbol, graphic mark is a symbol of certain thing, person or organization. The basis function of marks is to deliver the features and spirits of certain thing, person or organization to the public, for the social public's identification.

Graphic logo has become an important part of modern civilization. A brand represents the core idea and business philosophy of the enterprise. Its propaganda process is very important to the credibility, the survival and development of the enterprise. Graphics plays an important role in the establishment of the enterprise brand, the continuous improvement of its performance and the expansion of its scale. From the establishment to the development, an enterprise should establish a set of design concepts and corporate spirits suitable for itself. Graphics is a concentration of an enterprise's design concepts and corporate spirits. After continuous publicity and development, an enterprise brand will be widely recognized. Today's famous trademarks have become a symbol of one spirit, a symbol of status, a manifestation of the value of a person or a display of corporate image.

Graphics is a special cultural phenomenon in modern information communication. It is a kind of international visual language. It is a descriptive picture. Its characteristics are different from photography, painting and illustration. We are in an information society. People can exchange their thoughts and feelings and ideas through graphics, so the function of graphic design is increasingly important. Graphic language can summarize and simplify complex and cumbersome things through abstract and plane technique. It takes out secondary and excess parts, and strengthens the relationship of subject and part.

\section{Attractiveness}

Tourism poster graphics can attract viewers' attention in a moment. It effectively uses the "visual effect" of the graphics to attract the attention of viewers. Only graphics can achieve the effect of attracting viewers' attention in a moment. It hunts viewers' psychological reaction, and attracts attention of viewers. It is the "inductive effect" of tourism poster. Only by grasping people's sights in a moment, can it further guide consumers to read the text of the tourism poster. Then convert consumers from "attention" to conscious or unconscious "memory". It persuades and induces consumers to consume. From simulating consumer motivation to facilitating consumer behavior, it finally achieves the purpose of tourism poster. We can see tourism poster graphic design everywhere. When we read newspaper, magazine, or walk along the street, we can see all kinds of dizzying tourism posters. The tourism poster graphic design needs to completely digest the theme of the poster program, accurately convey the theme of tourism posters, and make the viewer easy to understand and accept the information of commercial posters. Only by integrating theme and expression skills and perfectly combining its content with forms, can it have strong and individual exhibition effect, and vividly play its appeal function.

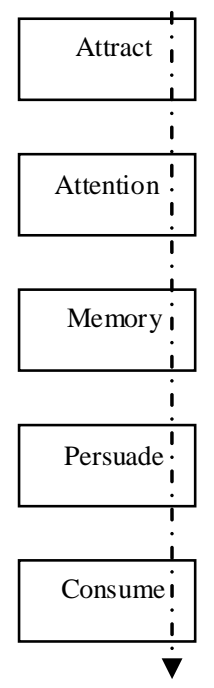

It is the main function of graphic design to fully and accurately transmit information. Human have always been exploring the visual communication of ideas, thoughts and feelings, just like we have transited from the industrialized society to today's information society. We can completely transform our ideas, thoughts and feelings into visual information for exchange and communication. Therefore, graphic design becomes an ideal communication way of people's ideas, thoughts and feelings. As early in 1921, Germany Paul Klee has referred that graphics was an expressive way of human feelings in his teaching note about "graphics learning thesis". The basic purpose of design is for certain specific problem, so designers should consider the effectiveness and accurateness of information communication and the understanding of viewers. The accurateness of this information communication is the primary objective of designers.

\section{THE EXPRESSIVE FORMS OF GRAPHICS}

The expressive forms of tourism poster graphics are very rich, and with a strong infectivity. As a visual art, it emphasizes the perceptual effect. This perceptual effect is not simple diagram of poster text. On the one hand, poster uses graphics to stimulate people's curiosity. On the other hand, the poster graphics attracts people's attention. Thus, it converts to a continuous memory and achieve the effect of publicity. When people read the poster, they can easily understand its theme. Graphics can strongly and deeply stimulate and shock viewers' mind and emotion. Visual image has the power to evoke a variety of emotions. It is a tempting way to combine graphic 
poetry with the artistry of visual media, which has the function of scene evocation.

In many cases, the position of graphics is more eyecatching than that of text in tourism poster. In the promotion of goods, graphics has the same important role with text, and sometimes even plays a greater role than text. The function of graphics is more direct and effective, and faster in conveying the information of poster.

Poster graphics induces consumers and stimulate consumers' psychological reaction, and then guide their sight to text. Poster graphics can link the content of tourism posters with consumers, and attract attention.

\section{THE SENSE OF ORDER IN THE TOURISM POSTER GRAPHICS}

The formation of any tourism poster graphics is expressed through certain constitution form. And every form of constitution is a form of order. In nature, it is not difficult to find some strange and regular combinations. For example, flowers have symmetric combination of petals; beans are well arranged in bean pod. The example, like lotus seeds, corn, spike and wheat, is too numerous to mention individually. The regular and order arrangement is the natural order Gombrich said. Then, how does the natural order generate? Gombrich replied: "the premise of the natural order is that the physical laws are able to play their role in an isolated and undisturbed system." [6]

All things in nature are mutually influenced and interacted. It is because of the disorder in the complex environment of nature that order has aroused our consciousness. The specific patterns of plants and animals in nature have showed us this point. One is the camouflage pattern formed on the surface of animal body in order to survive. The other is the striking pattern formed on the surface of the animal body in order to attract attention. It can be seen that these patterns are not generated by chance. They have a high value of information.

Since there is a natural order, there must be an artificial order. People may not understand how do human beings achieve the inherent abstract program through straight line structure. In fact, it is not difficult to understand this problem. People like techniques and skills. Why there are many geometric components in the artificial order? It is because geometric components are very rare in nature. It is so few that there is almost no chance to make an impression in the minds of the people. The conclusion showed that human brain chose the regular expressive forms due to rare geometric components. It is generally accepted that regular expressive forms are the products of the human brain with control ability, because they are in sharp contrast to the disordered state of nature.

No matter how we analyze the difference between regular structure and irregular structure, we shall explain the fact of aesthetic aspects that the aesthetic pleasant sensation comes from the observation of graphics between boring state and messy state. That is to say, the monotone graphics is difficult to attract people's attention. Too complex graphics will make our perception system overload and dazzling, and stop people's appreciation.
Inspired by nature, human beings have developed rich constitution forms. What kind of order constitution can produce a relatively strong visual effect to adapt to the constitution form of tourism poster graphics?

In the tourism posters, strengthening expression techniques, including breaking, repeat, replacement and dynamic sense, especially the sense of movement, is always a symbol of organic vitality. The perceptibility of visual sense to movement is due to external stimulation. In other words, people's mental function has corresponding relationship with the structural characteristics of visual object. Under external stimulation, the visual and perceptual sense makes human experience a kind of tensile force. Originally, to feel the tensile force is through tactile sense, rather than visual sense. However, the universal gravitation affects people's psychological feelings, and the role of the "force" affects people's feelings. The concept of force field affects people's appreciation quality to a great extent. In general, a variety of graphics have a sense of movement. But they are very different in strength. There are potential sense of movement (trend of movement) and formal sense of movement. Therefore, whether the "tensile force" has obvious tendency is the key for tourism poster to produce a sense of movement.

The final goal of tourism poster graphics is to attract viewers' attention in an instant, so as to guide viewers to read the text of the tourism poster. It guides consumers and promotes sales. Designers should grasp the consumer psychology in the creative design of tourism poster graphics. Only by making more efforts to play its work, can the tourism poster graphics improve the quality of tourism poster and realize the goal of tourism posters.

\section{Visual PENETRATION OF TOURISM POSTER GRAPHICS}

Lacan's theory of mirror stage referred to the "imitation". It means to imitate the commodities in the picture. Consumers may produce the "performance of animal mimicry"1 after stimulated by graphical goods visually. In other words, consumers may agree with the poster graphics in order to be recognized by the surrounding environment.

The meaning of graphics may change constantly in the long-term development process. The application of graphics in tourism poster should also actively change in order to adapt to the need of different groups. For example, directly refine and abstract product image, and give it with a certain meaning. Graphics abstraction has been separated from the pure imitation. It has a function of decoration and beautification. It enables tourist poster graphics to produce the penetration function to abstract the picture of commodity.

The viewers will have a memory when they see the poster repeatedly. In later life, they see graphics as if they see products or enterprises. The permeability of graphics has generated. In China Unicom's propaganda poster, it is enough to explain everything with just a Unicom logo. Graphical Chinese knot represents that China Unicom connects the whole world. Viewers see this graphics as if they see China Unicom. It is a penetration manifestation of graphics. 


\section{REFERENCES}

[1] Stott. Principles and Pragmatism of Advertising Psychology. Beijing: The Open University of China Press, 1900.

[2] E.H. Gombrich. Sense of Order. Changsha: Hunan Science and Technology Press, 2005: 110-158.

[3] Wang Xiaosheng. Modern Poster Design. Shanghai: Fudan University Press, 2002.

[4] Maslow. Exploration of Existential Psychology. Kunming: Yunnan People's Publishing House, 1987. 